\title{
Economics \\ and Business \\ Review
}

\section{Volume 1(15) Number 32015}

\section{CONTENTS}

\section{Introduction}

Piotr Manikowski, W. Jean Kwon

\section{ARTICLES}

The changing architecture of the safety net in insurance worldwide: post-crisis developments

Jan Monkiewicz, Lech Gąsiorkiewicz, Marek Monkiewicz

The determinants of nonlife insurance penetration in selected countries from South Eastern Europe

Klime Poposki, Jordan Kjosevski, Zoran Stojanovski

Microeconomic and macroeconomic determinants of the profitability of the insurance sector in Macedonia

Tanja Drvoshanova-Eliskovska

Policyholder and insurance policy features as determinants of life insurance lapse evidence from Croatia

Marijana Ćurak, Doris Podrug, Klime Poposki

Longevity risk and the design of the Polish pension system

Marek Szczepański

Polish farmers' perception of spring frost and the use of crop insurance against this phenomenon in Poland

Monika Kaczała, Dorota Wiśniewska

Insurance and risk management systems in Russia

Nadezda Kirillova

\section{BOOK REVIEWS}

Jeremy Rifkin, Zero Marginal Cost Society. The Internet of Things, the Collaborative Commons, and the Eclipse of Capitalism, Palgrave Macmillan, New York 2014 (Jan Polowczyk)

Andrzej Rzońca, Kryzys banków centralnych. Skutki stopy procentowej bliskiej zera [Central Banks Crisis. The Impact of Interest Rates Close to Zero], Wydawnictwo C.H. Beck, Warszawa 2014 (Tadeusz Kowalski) 


\author{
Editorial Board \\ Ryszard Barczyk \\ Witold Jurek \\ Cezary Kochalski \\ Tadeusz Kowalski (Editor-in-Chief) \\ Henryk Mruk \\ Ida Musiałkowska \\ Jerzy Schroeder \\ Jacek Wallusch \\ Maciej Żukowski
}

\title{
International Editorial Advisory Board
}

Udo Broll - School of International Studies (ZIS), Technische Universität, Dresden

Wojciech Florkowski - University of Georgia, Griffin

Binam Ghimire - Northumbria University, Newcastle upon Tyne

Christopher J. Green - Loughborough University

John Hogan - Georgia State University, Atlanta

Bruce E. Kaufman - Georgia State University, Atlanta

Steve Letza - Corporate Governance Business School Bournemouth University

Victor Murinde - University of Birmingham

Hugh Scullion - National University of Ireland, Galway

Yochanan Shachmurove - The City College, City University of New York

Richard Sweeney - The McDonough School of Business, Georgetown University, Washington D.C.

Thomas Taylor - School of Business and Accountancy, Wake Forest University, Winston-Salem

Clas Wihlborg - Argyros School of Business and Economics, Chapman University, Orange

Jan Winiecki - University of Information Technology and Management in Rzeszów

Habte G. Woldu - School of Management, The University of Texas at Dallas

\section{Thematic Editors}

Economics: Ryszard Barczyk, Tadeusz Kowalski, Ida Musiałkowska, Jacek Wallusch, Maciej Żukowski • Econometrics: Witold Jurek, Jacek Wallusch • Finance: Witold Jurek, Cezary Kochalski • Management and Marketing: Henryk Mruk, Cezary Kochalski, Ida Musiałkowska, Jerzy Schroeder • Statistics: Elżbieta Gołata, Krzysztof Szwarc

Language Editor: Owen Easteal • IT Editor: Piotr Stolarski

(C) Copyright by Poznań University of Economics, Poznań 2015

Paper based publication

ISSN 2392-1641

POZNAŃ UNIVERSITY OF ECONOMICS PRESS

ul. Powstańców Wielkopolskich 16, 61-895 Poznań, Poland phone +48 $618543154,+48618543155$, fax +48 618543159 www.wydawnictwo-ue.pl, e-mail: wydawnictwo@ue.poznan.pl postal address: al. Niepodległości 10, 61-875 Poznań, Poland

Printed and bound in Poland by:

Poznań University of Economics Print Shop

Circulation: 300 copies 


\section{BOOK REVIEWS}

Jeremy Rifkin, Zero Marginal Cost Society. The Internet of Things, The Collaborative Commons, and the Eclipse of Capitalism, Palgrave Macmillan, New York, 2014: 356, ISBN 978-1-137-27846-3

Jeremy Rifkin is an American economic and social theorist, lecturer, and political advisor. He is the author of many books about the impact of technological changes on the economy and society. He has written above 20 books since 1973 . Rifkin's work has also been controversial. Opponents have attacked the lack of scientific rigor in his claims. His most recent book is The Zero Marginal Cost Society.

The last Rifkin's book consists of five parts and their titles can be treated as the shortest summary: The untold history of capitalism, The near zero marginal cost society, The rise of the collaborative commons, Social capital and the sharing economy, and The economy of abundance. The last part presents the summary of the Rifkin's post-capitalist age vision.

Rifkin's reasoning is based on historical comparisons and present technology trajectories. The initial infrastructure of both the first and second industrial revolutions in America and Europe was put in place in 30 years, and matured in another 20 years. The first industrial revolution was peaking in the last two decades of $19^{\text {th }}$ century. The second industrial revolution was being born in that time in America and Europe. The discovery of oil, the invention of the combustion engine, and the introduction of the telephone started a new communi- cation/energy complex that would dominate the $20^{\text {th }}$ century. According to Rifkin, the second industrial revolution peaked and crashed in July 2008, when the price of crude oil hit a record $\$ 147$ a barrel on world markets.

The foundation of the first and second industrial revolutions was a high concentration of economic power. Vertically integrated corporates were the most efficient means of organizing the production and distribution of mass produced goods and services. They reduced transaction costs, increased productivity, lowered the marginal costs of production and distribution, and lowered the price of goods and services, allowing the economy to flourish. While those at the top of the corporate pyramid benefited the most from the increasing efficiency, the living standard of the masses also improved.

According to Rifkin (pp. 70-71) we meet the ultimate contradiction at the heart of capitalist system. The driving force of the system is greater productivity. The competitors race to introduce new technologies lowers their production costs and the price of their products and services. The finish line of the race is where the marginal cost of producing each additional unit is nearly zero. When the race is finished, goods and services become nearly free, profits dry up, the exchange 
of property in markets shuts down, and the capitalist system dies.

The leap in productivity is possible because the emerging Internet of Things (IoT) is the first smart infrastructure in history. In the future it will connect every machine, vehicle, residence and business in an intelligent network comprised of a Communications Internet, Energy Internet, and Logistic Internet. According to Rifkin, before 2040 most of the energy to heat houses, power plants and drive vehicles, will be nearly free.

A new manufacturing model called 3D printing is developing exponentially along with the other components of the IoT infrastructure. More and more companies are now producing physical products the way software produces information in the form of video, audio, and text. The Energy Internet (a merger of Internet technology and renewable energies) will change the way power is generated and distributed. In the next decades hundreds of millions of people will produce their own renewable energy in their homes, offices, and factories, and share green electricity with each other on an Energy Internet, just as we now generate and share information online. It will allow billions of people to share energy at near zero marginal cost in an IoT net.

The IoT will stimulate developments of collaborative commons. For a long time economists regarded the commons as a unique economic model connected to feudal society. Over the past 25 years, a younger generation of scholars and practitioners has begun to rediscover the commons as a governing model. Cooperative is an autonomous association of persons united voluntarily to meet their common economic, social, and cultural needs and aspirations through a jointly-owned and democratically controlled enterprise. Cooperatives are based on the values of self-responsibility, democracy, and equality. Cooperative members believe in the ethical values of honesty, openness, and social responsibility (p. 211).

The first and the second industrial revolutions required huge sums of capital, and therefore had to be organized in vertically integrated enterprises under centralized control to achieve economic of scale. The third industrial revolution based on IoT requires less finance capital and more social capital, scales laterally rather than vertically, and is best implemented by a commons management rather than by capitalist market mechanism.

The traditional capitalistic system is defined by private property. According to Rifkin (p. 225), the privately owned car can be the signature item. A car reflects the desire to be free. But for Internet generation freedom means the ability to optimize one's life by the diversity of experiences. Freedom is measured more by access to networks sharing products and services than ownership of property in markets. Freedom for Internet generation is the ability to collaborate with others, in a peer-to-peer world via Internet.

There are two kinds of a sharing economy benefits: rational and emotional (p. 252). The rational benefits given by respondents are the following: saving money, impact on the environment, lifestyle flexibility, practicality of sharing, easy access to goods and services. As for emotional benefits, respondents mentioned above all generosity, followed by a feeling of being a valued part of a community, being smart, being more responsible, and being a part of a movement.

When marginal costs drop to near zero, profits disappear. Goods and services will be essentially free. When most things become nearly free, the operat- 
ing rationale of capitalism as an organizing mechanism to produce and distribute goods and services becomes meaningless. That is because capitalism's dynamism feeds off scarcity. If goods and services are scarce, they have exchange value and can be priced in the markets. "Free in price" implies "free from scarcity" (p. 273). According to Rifkin's theory, it means that, if marginal costs of producing additional units of a good or service is nearly zero, scarcity has been replaced by abundance.

The third industrial revolution is following faster. The World Wide Web went on line in 1990 and matured by 2014, connecting much of the human race across a communications medium that operates at near zero marginal costs. The same exponential pattern of Communications Internet growth is moving the Energy Internet forward on a similar timeline, with the prospect of approaching near universal generation of green electricity in many countries at near zero marginal cost in 25 years. The Logistics Internet, although still in its infancy, is likely to run apace. As for 3D printing, it is already experiencing a faster growth trajectory than the Communnication Internet at a comparable stage of development.

Rifkin's vision of the future is quite consistent and comprehensive. Technological progress will reduce costs and prices of products and services. The exponential growth of computers power according to the Moore's law will push the similar changes in renewable energy and logistics. We have experienced these phenomena during two last decades. Rifkin predicts that this trend will lead to a significant reduction in marginal costs, and that they will be close to zero. As a result, it will lead abundance of goods and the general welfare. And it is the weakest element of his forecast.
The crucial concept of the Rivkin's theory is a marginal cost. Marginal cost is the term used in economics and business to refer to the increase in total production costs resulting from producing one additional unit of the item. Rifikin did not present theoretical background and academic discussion connected with marginal costs, although he presented many other economics concept like for example: relations between technological innovations and productivity (by O. Lange and J.M Keynes), collaborative commons (by E. Ostrom), transactional costs (by R. Coase), or individual happiness (by R. Layard). Textbooks of economics theory teach that marginal costs first go down, but then bottom out and begin to rise again as quantity increases. In the Rifkin's concept marginal cost does not include initial investment and overhead costs (p. 273). Rifkin describes a world of free fixed costs (e.g. free wi-fi for everyone). To some extent this is happening right now.

It is very difficult to defend the thesis that scarcity will disappear. Each new product or service innovation at the beginning is a scarce resource and is expensive. Step by step, following the cumulative experience, the costs and prices are dropping. And prices, as a basic indicator of scarcity will not disappear. The progress we experience in the last two centuries is stimulated by a constant tension of competition an cooperation. Collaborative commons can disseminate by IoT support and enrich the diversity of our societies, but it is doubtful that they will replace competitive markets.

Rifkin's book is regarded as the counterpoint to T.Piketty's Capital in the Twenty-first Century. Rifkin argues for an optimistic outlook for the rest of this century while Piketty argues for a pessimistic vision. The real future 
will probably be a combination of both views.

And the additional remark for readers: the last book by Rifkin is not very friendly for reading. It consists of above 300 pages with high density of rows, without tables or figures, which could improve perception of the author's concepts.

Jan Polowczyk

Poznań University of Economics

Faculty of International Business and Economics 
Andrzej Rzońca, Kryzys banków centralnych. Skutki stopy procentowej bliskiej zera [Central Banks Crisis. The Impact of Interest Rates Close to Zero], Wydawnictwo C.H. Beck, Warszawa 2014: 542, ISBN 978-83-255-5544-3

The book under review deserves attention, both because of its subject matter and because its author is a member of the Monetary Policy Council. The work is aimed at readers who are interested in central banking as well as those professionally involved in the issues of monetary policy and in particular the current interest rates close to zero. The book is also an important academic source on contemporary economic policy.

In $201590 \%$ of the world's developed economies have a zero interest rate. Shortterm interest rates as low as they are today are unusual. In the economic history of the world only two periods (around 1895 and in the second half of 1930s) were marked by short-term interest rates remaining very close to zero. These conditions undoubtedly pose a challenge for theoreticians and, above all, practitioners, who must take decisions which potentially and actually influence nominal and real variables as well as for those observing the open economy macroeconomics in the Polish and global contexts.

The question of modern interest rate volatility and its real value at close to zero or even a negative value should be considered as one of the main effects of the global crisis that require careful analysis. This is also caused by a high degree of liquidity in the global economy which, in conjunction with budget deficits, significantly reduces the influence of monetary and fiscal policy instruments on key macroeconomic variables.

The author is a recognized expert in the field of central banking and monetary policy and has previously published works on interest rates and the said policy. Andrzej Rzońca's works, mainly co-authored, with a few exceptions are the only Polish titles used in the bibliography of the reviewed book. On the one hand this reflects the status of the author and on the other it expresses his assessment of Polish specialist literature on the subject.

This extensive work of 542 pages has an eloquent style. The author aims at presenting existing literature published in English and thus brings this element of modern economics closer to the Polish reader. In the introduction the author declares that the book will endeavour to answer a number of questions of which (p. 7) the most important is: "[...] why, despite the period of six years since the outbreak of the crisis, economic recovery has been so weak" (reviewer's note: in the USA and in the eurozone). Other questions posed by Andrzej Rzońca are (p. 7):

"Why do so few entities start [...] business activity, even when - as in the United States today - the net profits of enterprises are the highest in history in relation to GDP?

Why is staff turnover so low?

Why is the variability of macroeconomic indicators similar to the historical low and does not reflect this uncertainty?"

In my opinion the common denominator is that they relate to objective phenomena and processes which have their primary sources in technology and structural changes in the global economy including its real sector. The author is certainly aware of these variables but he does not attribute them their proper meaning in his choice of factors. 
The work opens with a chapter entitled Introduction to the analysis. This provides an overview and a presentation of the basic concepts and the approach to the analysis. It refers to previous research on the impact of interest rates close to zero.

Chapter Two - The impact of the potential sustainability of the natural interest rate at a low level-includes a discussion of the new Keynesian analytical framework for monetary policy, the relationship between central bank policy and the natural interest rate, as well as the potential impact of central bank operations on the expectations of economic entities.

The following chapters, are devoted to the impact of an interest rate close to zero on: restructuring and uncertainty after the crisis, credit and other forms of external financing, the ability of the central bank to increase money supply and finally the state of public finances.

Chapter Seven - Observations from Japan, compared to Sweden and South Korea - is empirical. The author uses his findings from the previous chapters and based on reports and literature gives an account of the course of events in these three countries.

Chapter Eight - Conclusions from the analysis - recommendations for monetary policy - closes the work. The recommendations split into three main areas: "interest rate policy after the outbreak of the financial crisis", the issue of "quantitative easing and the monetary policy in the countries that do not suffer from the financial crisis due to the unconventional measures taken by major central banks".

The book uses and brings the current global state of knowledge on the subject to the Polish readers. The work is a valuable educational tool for all those interested in the problems of contemporary central banking. The author's own analytic diagrams that visualize his outlook on the transmission mechanisms of interest rates close to zero on the financial and the real sector are particularly valuable.

The author's book raises expectations with regard to the totality of the contents and literature. Whilst the first chapter is an introduction and serves as a foundation for further considerations its overall scope leaves the reader unsatisfied. In my opinion the author missed the key factors underlying the current situation concerning the interest rates of central banks probably in order to ensure conciseness and to focus on transmission channels.

The attempt to understand the current challenges faced by central banks today will be one-sided, if the following factors are not taken into account: changes in technology, structural changes in the global economy related to the supply and demand shocks created after China entered the global economy, the mistakes of central banks (mainly those of FED after 2001). These factors significantly changed the central banks' operational environment as the banks faced the problem of a drastic decrease in inflation and expectations of inflation (the loss of directional indicators in the form of inflation) and a drop in real market interest rates. Without a brief reference to that situation it is impossible to correctly answer the questions that the author himself posed in the introduction to his book.

The subject matter of the book is important and timely. The work will serve as an inspiration for further research including empirical studies.

Tadeusz Kowalski Poznań University of Economics Faculty of International Business and Economics 


\begin{abstract}
Aims and Scope
Economics and Business Review is the successor to the Poznań University of Economics Review which was published by the Poznań University of Economics Press in 2001-2014. The Economics and Business Review is a quarterly journal focusing on theoretical and applied research work in the fields of economics, management and finance. The Review welcomes the submission of articles for publication dealing with micro, mezzo and macro issues. All texts are double-blind assessed by independent reviewers prior to acceptance.
\end{abstract}

\title{
Notes for Contributors
}

1. Articles submitted for publication in the Economics and Business Review should contain original, unpublished work not submitted for publication elsewhere.

2. Manuscripts intended for publication should be written in English and edited in Word and sent to: review@ue.poznan.pl. Authors should upload two versions of their manuscript. One should be a complete text, while in the second all document information identifying the author(s) should be removed from files to allow them to be sent to anonymous referees.

3. The manuscripts are to be typewritten in 12' font in A4 paper format and be left-aligned. Pages should be numbered.

4. The papers submitted should have an abstract of not more than 100 words, keywords and the Journal of Economic Literature classification code.

5. Acknowledgements and references to grants, affiliation, postal and e-mail addresses, etc. should appear as a separate footnote to the author's name ${ }^{\mathrm{a}, \mathrm{b} \text {, etc }}$ and should not be included in the main list of footnotes.

6. Footnotes should be listed consecutively throughout the text in Arabic numerals. Cross-references should refer to particular section numbers: e.g.: See Section 1.4.

7. Quoted texts of more than 40 words should be separated from the main body by a four-spaced indentation of the margin as a block.

8. Mathematical notations should meet the following guidelines:

- symbols representing variables should be italicized,

- avoid symbols above letters and use acceptable alternatives $\left(\mathrm{Y}^{*}\right)$ where possible,

- where mathematical formulae are set out and numbered these numbers should be placed against the right margin as... (1),

- before submitting the final manuscript, check the layout of all mathematical formulae carefully (including alignments, centring length of fraction lines and type, size and closure of brackets, etc.),

- where it would assist referees authors should provide supplementary mathematical notes on the derivation of equations.

9. References in the text should be indicated by the author's name, date of publication and the page number where appropriate, e.g. Acemoglu and Robinson [2012], Hicks [1965a, 1965b]. References should be listed at the end of the article in the style of the following examples:

Acemoglu, D., Robinson, J.A., 2012, Why Nations Fail. The Origins of Power, Prosperity and Poverty, Profile Books, London.

Kalecki, M., 1943, Political Aspects of Full Employment, The Political Quarterly, vol. XIV, no. 4: 322-331.

Simon, H.A., 1976, From Substantive to Procedural Rationality, in: Latsis, S.J. (ed.), Method and Appraisal in Economics, Cambridge University Press, Cambridge: 15-30.

10. Copyrights will be established in the name of the E\&BR publisher, namely the Poznan University of Economics Press.

More information and advice on the suitability and formats of manuscripts can be obtained from:

\section{Economics and Business Review}

al. Niepodległości 10

61-875 Poznań

Poland

e-mail: review@ue.poznan.pl

www.puereview.ue.poznan.pl 


\section{Subscription}

Economics and Business Review (E\&BR) is published quarterly and is the successor to the Poznań University of Economics Review. The E\&BR is published by the Poznań University of Economics Press.

E\&BR is listed in ProQuest, EBSCO, and BazEkon.

Subscription rates for the print version of the E\&BR: institutions: 1 year $-€ 50.00$; individuals: 1 year $-€ 25.00$. Single copies: institutions - $€ 15.00$; individuals $-€ 10.00$. The $\mathrm{E} \& \mathrm{BR}$ on-line edition is free of charge.

Correspondence with regard to subscriptions should be addressed to: Księgarnia Uniwersytetu Ekonomicznego w Poznaniu, ul. Powstańców Wielkopolskich 16, 61-895 Poznań, Poland, fax: +48 61 8543147; e-mail: info@ksiegarnia-ue.pl.

Payments for subscriptions or single copies should be made in Euros to Księgarnia Uniwersytetu Ekonomicznego w Poznaniu by bank transfer to account No.: 96109014760000000047031245 . 